\title{
Worldwide Sustainability Hotspots in Potato Cultivation. 2. Areas with Improvement Opportunities
}

\author{
F.K. van Evert*, F.J. de Ruijter, J.G. Conijn, B. Rutgers, A.J. Haverkort
}

F. K. van Evert $\left({ }^{\star}\right) \cdot$ F. J. de Ruijter $•$ J. G. Conijn $・$ B. Rutgers $・$ A. J. Haverkort

Plant Research International, Wageningen University and Research Centre, Droevendaalsesteeg

1, 6708 PB Wageningen, The Netherlands

e-mail: frits.vanevert@wur.nl

\section{A. J. Haverkort}

Faculty of Natural and Agricultural Science, Department of Plant Production and Soil

Science, University of Pretoria, Private Bag X20, Hatfield 0028, South Africa

\begin{abstract}
Agriculture has a large impact on the environment and retailers increasingly stimulate their suppliers to reduce the environmental impact of agricultural production. The environmental impact resulting from producing a commodity can be measured with a life cycle analysis (LCA) but performing an LCA is costly and time-consuming. In the first paper of this series a practical and general method to identify hotspot areas in crop production on a global scale was developed. The method was implemented for potatoes. The objective of the work reported here was to evaluate the tool and to identify improvement opportunities for each of seven indicators: yield, erosion risk, nitrogen surplus, depletion of water reserves, biocide use, carbon footprint, and impact on biodiversity. The tool produces realistic outputs that can be used to target improve-ment efforts and thus improves the use efficiency of limited resources. The tool can be expanded to produce similar results for other crops; methods to improve the resolution of the tool are discussed.
\end{abstract}

Keywords Biocide use - Carbon footprint - Depletion of water reserves - Erosion risk - Impact on biodiversity · Indicator threshold - Indicators · Land use efficiency. Nitrogen surplus $\cdot$ Sustainability. Yield

\section{Introduction}

Agriculture has a large impact on the environment. Farmers, businesses, the scientific community, and policy makers are engaged in efforts to decrease this impact without 
compromising food security. Of the above actors, the retailers at the end of the supply chain are in the most direct contact with consumers and are very sensitive to public opinion. Increasingly, retailers stimulate their suppliers to reduce the environmental impact of agricultural production. One example is the work initiated by Unilever (Pretty et al. 2008a, 2008b), another example is the Sustainable Agriculture Initiative (SAI; http://www.saiplatform.org). Recently, The Sustainability Consortium (TSC; http:// www.sustainabilityconsortium.org) was formed.

The first step in the process of reducing the environmental impact of a commodity is assessing its impact. The environmental impact of producing a commodity is typically determined by performing a life cycle assessment (LCA). LCA gives a detailed description of the environmental impact resulting from delivering a good or a service. LCA is widely accepted as the best available method of assessing environmental impact. However, performing an LCA is costly and time-consuming.

The Sustainability Consortium (TSC) is a consortium of retailers and their suppliers that develops and promotes science-based and integrated tools to improve informed decision making for product sustainability throughout the entire product life cycle across all relevant consumer goods sectors, including agricultural commodities. Recognizing that it is not practical to develop LCAs for all products, TSC has adopted a quick-scan approach where data and expert opinion are used to identify hotspots in supply chains, where hotspot is defined as "a unit process or phase of a product life cycle that has a potentially significant environmental or social impact" (note that this is the definition of "hotspot" which is used in the LCA literature; in this paper, we will use "hotspot area" for the concept in its original geographic meaning). Examples of hotspots in agriculture are energy use (off-farm for production of inputs such as fertilizers and biocides, and on-farm for traction, pumping of irrigation water, cooling of storage sheds), nutrient losses, and water use (for irrigation and processing). But it is clear that while for many agricultural commodities LCA is too detailed, the hotspot approach is likely not detailed enough. The reason is that the environmental impact of an agricultural production system is a function of its environment. The impact of producing a certain amount of a certain agricultural commodity in one environment may be very different from producing the same amount of the commodity in an environment with different biophysical, economic, or social characteristics. This can be demonstrated by considering two hotspots for potato production, namely leaching of nitrates and high demand for irrigation water. In potato production in the Columbia basin of the northwestern USA, both are critical. But in potato production in the Netherlands, demand for irrigation water is not critical (due to the temperate maritime climate) and nitrate leaching is a hotspot only on sandy soils.

The above points to a need to differentiate hotspots by environment and thus identify hotspot areas. In fact, TSC has started work in this direction. Social hotspots are already differentiated by geographic location. Also, TSC's Commodity Supply Chain Mapping Project aims to identify the likely source locations of agricultural commodities used within any given nation. The project has created a model that uses UN Food and Agriculture Organization (FAO) data to identify global trade networks, tracing imports of major agricultural commodities back to the most likely production sites by geographic area (C. M. Slay, University of Arkansas, personal communication).

In the first paper of this series, a practical method to identify biophysical hotspot areas on a global scale was developed and implemented for potatoes (Haverkort et al. 
2014). No effort was made to define indicator thresholds to identify areas where improvement opportunities exist that can be targeted by bodies such as TSC. Thus, the objective of the current paper is to discuss indicators and threshold values in order to identify geo-referenced improvement opportunities in potato production on a global scale. In addition to the indicators of Haverkort et al. (2014), we calculate carbon footprint and impact on biodiversity in order to provide a more complete analysis of environmental impacts.

\section{Materials and Methods}

Indicators

We used the indicators mapped in the first paper of this series, viz. potato yield, occurrence of steep slopes and precipitation deficit and high growing season temperatures (Haverkort et al. 2014). Additionally, nitrogen surplus, emission of greenhouse gases (GHG, expressed as $\mathrm{CO}_{2}$-eq) per ton of fresh potato yield, and late blight risk were considered and the potential impact of potato cultivation on biodiversity was recognized.

GHG emission per ton of fresh potato yield was calculated by summing four terms: (1) emissions due to seed production, biocides, and diesel use for operations on the farm (an average of $20 \mathrm{~kg} \mathrm{CO}_{2}$-eq per ton for table and starch potato (Haverkort and Hillier 2011)), (2) emissions from $\mathrm{N}$ fertilizer production and use (9.6 $\mathrm{kg} \mathrm{CO}_{2}$-eq per $\mathrm{kg}$ $\mathrm{N}$; based on ca. $10 \%$ nitrate- $\mathrm{N}$ in $\mathrm{N}$ fertilizer according to Jenssen and Kongshaug (2003) and on (in)direct soil emission according to IPCC tier one (IPCC 2006)), (3) emissions related to diesel use for irrigation (1.5 $\mathrm{kg} \mathrm{CO}_{2}$-eq per mm; based on an average of different values published by Haverkort and Hillier (2011)), and (4) (in)direct soil emissions from $\mathrm{N}$ in potato residues which are left in the field (both amount of residues and emission factors according to IPCC tier one, 2006).

National data on (chemical) $\mathrm{N}$ fertilizer use are taken from the database of Fertistat (2012). Many countries have unrealistically low fertilizer $\mathrm{N}$ application rates (Fig. 1a) when compared to national average potato yield (Monfreda et al. 2008). Based on observations in the Netherlands, potato requires an average $\mathrm{N}$ input of $5.3 \mathrm{~kg} \mathrm{~N}$ per ton fresh tuber yield (PPO 2012). Elsewhere this may be lower (e.g., Giletto and Echeverria
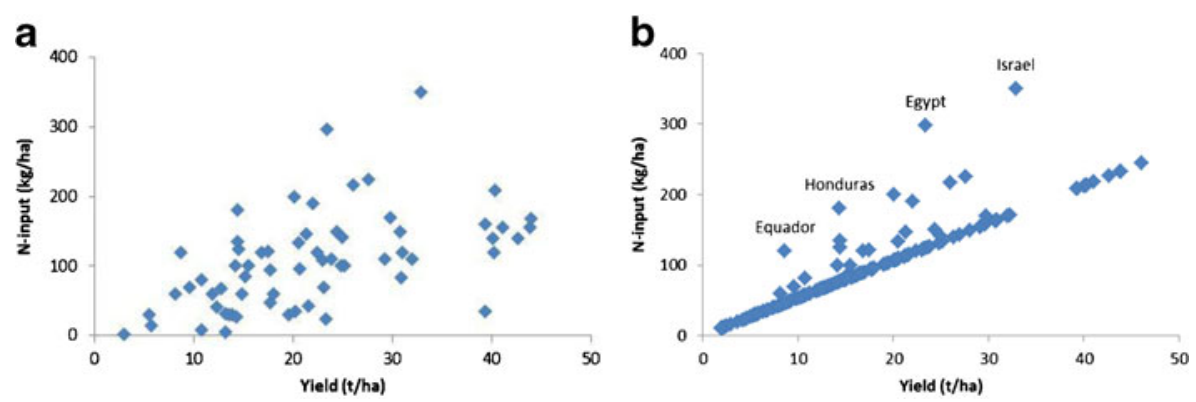

Fig. 1 Left a Relationship between chemical fertilizer $\mathrm{N}$ use per hectare per country for potato production, mostly based on expert judgement (IFA 2002 data). Right b All data points below a fertilizer N input of $5.3 \mathrm{~kg} \mathrm{~N}$ per ton of fresh tuber yield were moved up to this value 
2013), but we accepted the Netherlands number of $5.3 \mathrm{~kg} \mathrm{~N}$ per ton fresh tuber yield and therefore all data points below this level were moved up to this level to estimate each country's fertilizer N input (Fig. 1b). N surplus has been calculated by taking the difference between corrected fertilizer $\mathrm{N}$ input and the $\mathrm{N}$ off-take which was estimated by assuming a fixed $\mathrm{N}$ content of $0.22 \%$ in fresh tuber yield (e.g., Giletto and Echeverria 2013).

The amount of irrigation has been estimated by taking the precipitation deficit per grid cell (negative values in Haverkort et al. (2014), Fig. 4) if this grid cell contains irrigation equipment according to a global map of irrigation areas (Siebert et al. 2005, 2007). No irrigation is assumed in case of a precipitation surplus or if no irrigation equipment is available in a grid cell.

The risk of incurring yield losses due to infestation with late blight was assessed based on the work of Sparks (Sparks 2009; Sparks et al. 2011). In this work a detailed process-based ecological model was used to derive a metamodel which uses lowresolution input data of temperature and relative humidity and can therefore be applied worldwide.

Biodiversity is the degree of variation of life forms on Earth. Biodiversity provides economic and environmental benefits to humans, yet it has greatly decreased coincidently with the growth of the human population (e.g., Pimentel et al. 1997). Agricultural land use has a large impact on biodiversity. However, that impact is mediated through diverse mechanisms. Clearly, growing crops may reduce biodiversity by competing with natural vegetation and reducing the habitat for certain species. It may also increase biodiversity through diversification of habitat types. Biocides used to protect crops may reduce biodiversity by harming organisms and use of scarce water resources for irrigation may lead to a reduction in the area of wetlands and associated biodiversity (e.g., Turpie et al. 2003). Here we adopt the approach of specifying for each grid cell in which potato production takes place, whether that cell lies within a biodiversity hotspot. A biodiversity hotspot is defined as a region that meets two criteria: it must contain at least $0.5 \%$ or 1,500 species of vascular plants as endemics, and it has to have lost at least $70 \%$ of its primary vegetation (Myers 1988, 1990). For this we used the latest version of the map prepared by Conservation International (2011).

\section{Indicative thresholds}

The source data described and the data derived via calculations allowed us to derive seven indicator values (Table 1 ) for each cell of the global $5^{\prime} \times 5^{\prime}$ grid. While the maps that can be drawn from these data are informative, we have additionally sought to define indicative threshold values for each indicator. The intention of the indicative thresholds is to classify indicator values as either "likely not a sustainability issue" or "sustainability might be an issue here". The intention is to provide information so that when limited resources are available for further data collection or for carrying out improvement actions, these may be directed to those areas where action is most required or where the return of investment will likely be high.

For land use efficiency (i.e., potato productivity), we considered that any area with productivity lower than the global average likely has some issues which could be improved. Thus, we took the simple approach of setting the threshold for yield at the global average yield of $15 \mathrm{tha}^{-1}$. 
Table 1 Potential hotspots in potato cultivation

\begin{tabular}{|c|c|c|c|c|}
\hline Hotspot & Indicator & $\begin{array}{l}\text { Threshold for } \\
\text { attention }\end{array}$ & $\begin{array}{l}\text { Global } \\
\text { area affected } \\
(\%)\end{array}$ & $\begin{array}{l}\text { Global } \\
\text { tonnage } \\
\text { affected }(\%)\end{array}$ \\
\hline Low land use efficiency & Fresh tuber yield & $\begin{array}{l}<15 \mathrm{t} \mathrm{ha}^{-1} \\
\text { per harvest }\end{array}$ & 59 & 38 \\
\hline Soil erosion by run off & $\begin{array}{l}\text { Ratio (area of crop } \\
\text { land)/(area with } \\
\text { slope }<2 \% \text { ) }\end{array}$ & $>1$ & 62 & 59 \\
\hline $\begin{array}{l}\text { Fertilizer use, } \\
\text { nutrient leaching, } \\
\text { and nutrient run-off }\end{array}$ & Nitrogen surplus & $>60 \mathrm{~kg} \mathrm{~N} \mathrm{ha}^{-1}$ year $^{-1}$ & 40 & 54 \\
\hline $\begin{array}{l}\text { Depletion } \\
\text { of water reserves }\end{array}$ & Precipitation deficit & $>250 \mathrm{~mm}$ per cycle & 20 & 21 \\
\hline Biocide use & $\begin{array}{l}\text { Average daily } \\
\text { maximum temperature } \\
\text { (late blight risk+high } \\
\text { temperatures) }\end{array}$ & $\begin{array}{c}>25^{\circ} \mathrm{C} \text { or }>4.1 \\
\text { blight units }\end{array}$ & 11 & 13 \\
\hline Carbon footprint & $\begin{array}{l}\text { GHG emission } \\
\text { from cultivation }\end{array}$ & $\begin{array}{l}\text { 80th percentile } \\
\quad\left(140 \mathrm{~kg} \mathrm{CO} 2-\mathrm{eq}^{-1}\right)\end{array}$ & 21 & 12 \\
\hline Biodiversity & $\begin{array}{l}\text { On map of Conservation } \\
\text { International }\end{array}$ & $\begin{array}{l}\text { On map of Conservation } \\
\text { International }\end{array}$ & 17 & 15 \\
\hline
\end{tabular}

When potatoes are grown on slopes, there is a risk of water erosion. Slope is only one of the factors contributing to erosion risk, other factors being slope length, soil type, precipitation regime, and soil management. A globally applicable slope value beyond which erosion risk becomes significant can therefore not be defined objectively. Subjectively, we used a cut-off value of $2 \%$ slope, first because there is some evidence that erosion at lesser slopes is not significant (Smith et al. 2007), and second because it is the boundary between two slope classes in the data we used (Fischer et al. 2008). The slope data apply to the whole grid cell and it is not known whether the cropland in a cell is located on the sloping land or on the flat land. We assumed that crops (and potatoes in particular) will preferentially be grown on non-sloping land. The indicator for erosion risk is therefore the ratio of cropland area (all crops) and the area of land with slopes less than $2 \%$. A value of 1 is chosen as the threshold value because at this value all cropland could in principle be located on the area with $<2 \%$ slope, whereas at values $>1$ at least part of the cropland must be located on sloping land.

The $\mathrm{N}$ surplus of a crop is the amount of $\mathrm{N}$ added to the soil in the form of fertilizers and manure, minus the amount of $\mathrm{N}$ removed from the field in the form of crop products. $\mathrm{N}$ surplus is a good indicator for the amount of $\mathrm{N}$ that is potentially lost to the environment. For $\mathrm{N}$ surplus, we adopted a threshold value that is based on the World Health Organization (WHO) and European Union (EU) standard for drinking water of $11.3 \mathrm{~g}$ nitrate-N per liter of drinking water, and on a relationship between $\mathrm{N}$ surplus and nitrate concentration in ground water. This relationship is affected by soil type, groundwater table, and precipitation surplus (ADAS 2007; Schröder et al. 2007). In the Netherlands, lowest allowable $\mathrm{N}$ surplus for achieving the $11.3 \mathrm{~g} \mathrm{NO}_{3}-\mathrm{N} \mathrm{liter}^{-1}$ is $48 \mathrm{~kg} \mathrm{~N} \mathrm{ha}^{-1}$ (Schröder et al. 2007). This value is even lower in areas with a lower 
precipitation surplus such as the eastern UK (ADAS 2007). In this paper, the threshold for $\mathrm{N}$ surplus is set at a value of $60 \mathrm{~kg} \mathrm{~N}^{-1}$, which is $125 \%$ of this lower value.

Depletion of water reserves is not likely when the precipitation deficit is small, because in that case the crop is likely grown on stored soil moisture plus rainfall during the growing season. Depletion of water reserves is considered a possible issue when precipitation deficit is larger than the amount of water that can be stored in the upper soil layers. Water storage in the upper soil layers can easily be 100-200 mm, thus we consider that the crop is dependent on irrigation and there is a risk of depletion of natural water reserves when the precipitation deficit is $>250 \mathrm{~mm}$.

The threshold for blight risk was adopted from (Sparks 2009; Sparks et al. 2011): a value of 4.1 or higher is considered high risk. For temperature as indicator for the risk of occurrence of pests, no authoritative source could be identified. We used expert knowledge to put the threshold for average daily maximum temperature during the growing season at $25^{\circ} \mathrm{C}$.

It is not possible to base a threshold for carbon footprint on acceptable environmental impact. The only touchstone here is the global variation in this indicator. Thus we use the 80th percentile of the carbon footprint of all potatoproducing grid cells as threshold. This is similar to the approach used by Franke et al. (2011) to define a threshold for water use efficiency in potato production in the ecologically sensitive Sandveld region of South Africa. The main difference is that we use a global population of grid cells, whereas Franke et al. (2011) used a local population of growers.

The threshold for biodiversity that we adopt is whether or not the grid cell under consideration is marked on the biodiversity hotspot areas map of Conservation International (2011).

\section{Results}

The potential hotspot "Low yield" can be read directly from Haverkort et al. (2014), Fig. 1. Yields between 7.5 and $15 \mathrm{tha}^{-1}$ are mainly found in Eastern Europe, India, and China. Even lower yields are found in some tropical highlands. On 59\% of the global potato acreage yield is lower than $15 \mathrm{t} \mathrm{ha}^{-1}$; together, these areas produce $38 \%$ of the global tonnage.

The potential hotspot "Soil erosion" is shown in Fig. 2. In the mountainous regions of the Andes, southern Europe, the foothills of the Himalayas and central and southern China, it is likely that potatoes are grown in regions with significant $(>2 \%)$ slope. Grid cells where the area of cropland exceeds the available flat $(<2 \%$ slope $)$ area contribute $62 \%$ of global potato growing area and $59 \%$ of global potato production.

The potential hotspot "Depletion of water reserves" is shown in Haverkort et al. (2014), Fig. 4 where negative values indicate precipitation deficit. Most of the potato growing regions have some precipitation deficit such as the northern European plains, central China, and the eastern part of North America. Regions with moderate (up to $250 \mathrm{~mm}$ ) precipitation deficit are where the crop is grown during a dry winter such as in the Indo-Gangetic plains but also inland summer cropping systems in Turkey, Eastern Europe, and Northeastern China (Ningxia). Higher deficits (up to $500 \mathrm{~mm}$ ) are found in most of India, southern Russia, and some parts of North America. Severe deficits of 


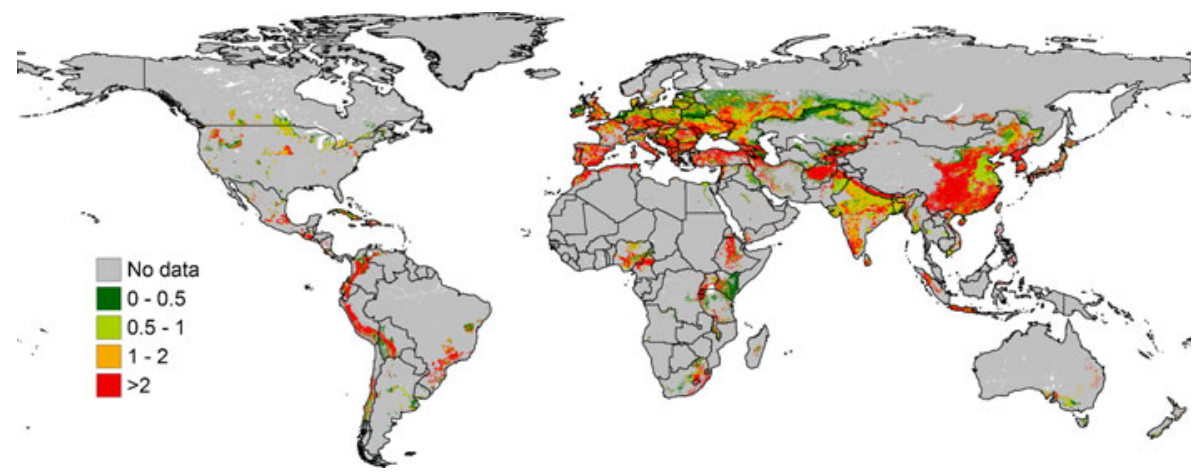

Fig. 2 Total cropland area in a grid cell divided by area of land with slope $<2 \%$, for grid cells where potatoes are grown. At values $<1$, all cropland could in principle be located on land with $<2 \%$ slope. At values $>1$, at least part of the cropland must be located on land with slope $>2 \%$

more than $500 \mathrm{~mm}$ are found in desert conditions such as in the western parts of North America and in the Central Andes. Globally, 20\% of the potato growing area has a precipitation deficit $>250 \mathrm{~mm}$ and the same proportion of global potato production is from areas where precipitation deficit is higher than this threshold.

The average national $\mathrm{N}$ surplus in potato cultivation is mapped in Fig. 3. High $\mathrm{N}$ surplus countries are situated in North America, Northwest Europe, South Africa, and Australia. Globally, $40 \%$ of potato growing area has a N surplus above the threshold of $60 \mathrm{~kg} \mathrm{~N} \mathrm{ha}{ }^{-1}$ and $54 \%$ of global potato production is from these areas.

The average daily maximum temperature during the growing season is shown in Haverkort et al. (2014), Fig. 5. High values occur in the lowlands in South America, in East and South Africa, and in India. The late blight pressure map of the world is shown in Fig. 4. Late blight pressure occurs mainly in the highlands of Mexico (home of the disease), the humid Andes in Ecuador and Colombia, maritime Northwestern Europe, the tropical highlands in Africa, the highlands in Asia, and the lowlands of Korea and Japan, especially Hokkaido.

The carbon footprint of potato production exceeds our threshold in the Andes, in southern Russia, in India, and in most of China (Fig. 5).

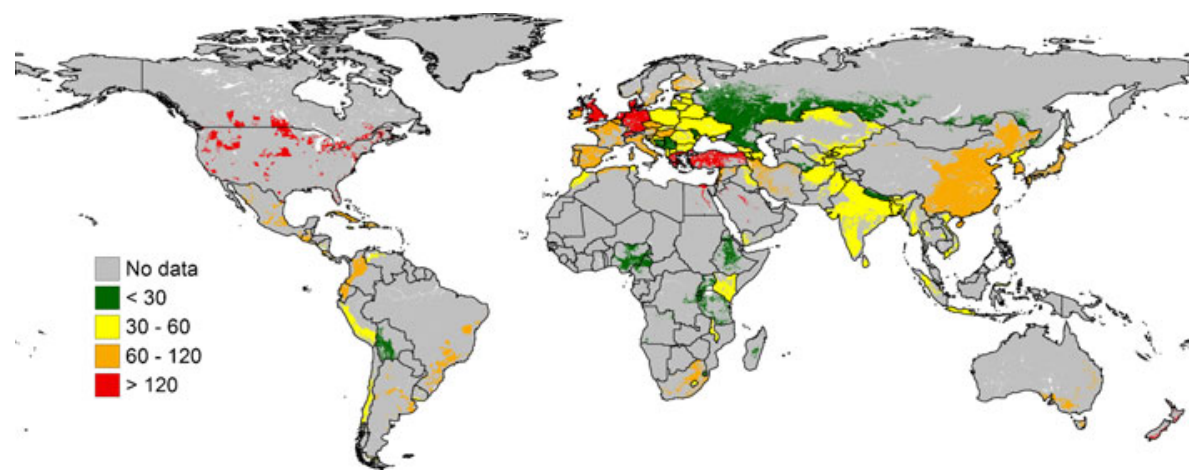

Fig. 3 Average nitrogen surplus ( $\mathrm{N}$ fertilization minus $\mathrm{N}$ harvested) of potato cultivation $\left(\mathrm{kg} \mathrm{N} \mathrm{ha}^{-1}\right.$ cycle $\left.^{-1}\right)$. Note that the data are given on a per-country basis (see Fig. 1), unlike the data in the rest of the paper which are given per grid cell 


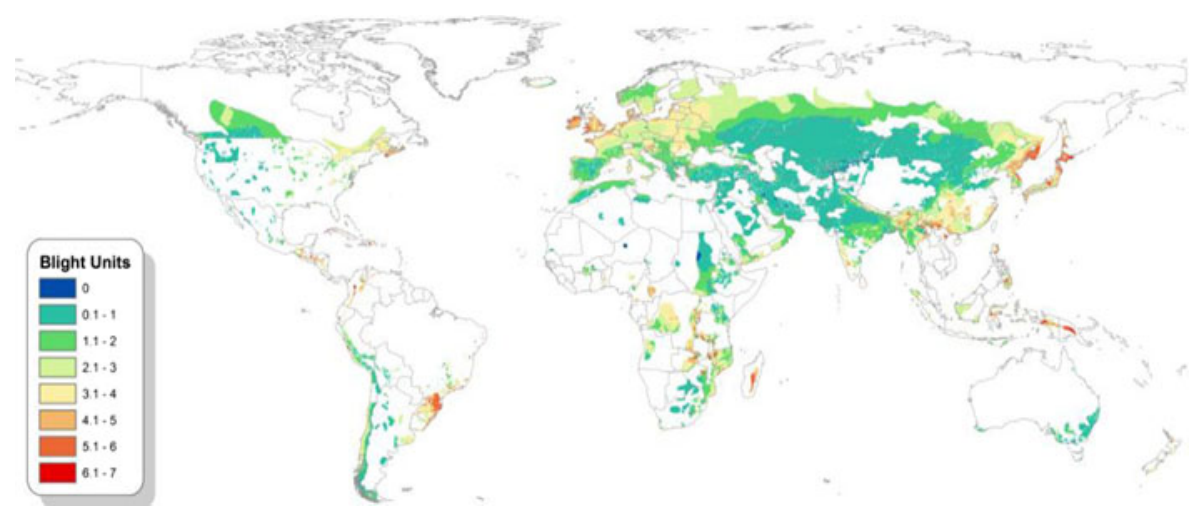

Fig. 4 Average late blight risk from 1961 to 1990 for a susceptible potato cultivar, expressed as the sum of blight units for the highest yielding 3 month growing season per locality for potato growing areas only. From Sparks (2009). Reproduced with permission

Potato production in areas that are marked as biodiversity hotspots can be found mainly in the tropical Andes, in the Valdivian temperate rainforests in Chile, in the Mediterranean Basin, and in the Himalayas (Fig. 6).

\section{Discussion}

The results obtained with our tool are in line with expert knowledge. The yield data in Haverkort et al. (2014), Fig. 1, can be explained in terms of underlying geographic, economic, and social conditions. The low yields in some tropical highlands can be explained by limited use of resources such as good quality seed, fertilizers, and crop protectants. Medium yields of 10-20 t are mainly found in central and Eastern Europe, India, and China. In some of these regions, yields are limited by a short growing season such as in the northern part of North America, central and Eastern Europe, and North China, Korea, and Japan (Hokkaido). In the sub-tropics, potatoes are grown during the winter to escape excessive heat and yields are low, both because the growth period is not more than 100 days and because of limited insolation during this period due to short days and low solar elevation. Examples are the Indo-Gangetic plains, southern China,

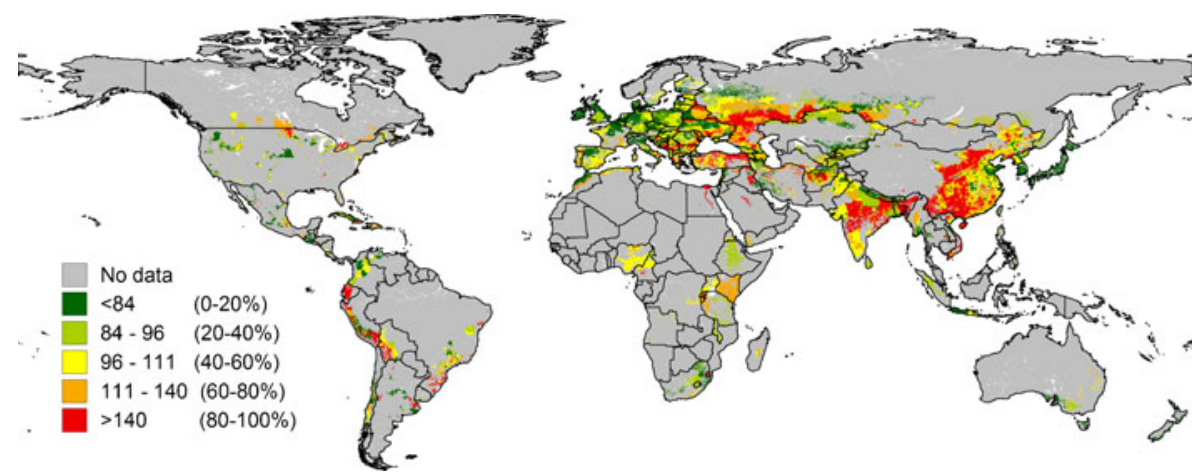

Fig. 5 GHG emission per ton fresh potato yield $\left(\mathrm{kg} \mathrm{CO}_{2}\right.$-eq $\left.\mathrm{t}^{-1}\right)$. See text for explanation 


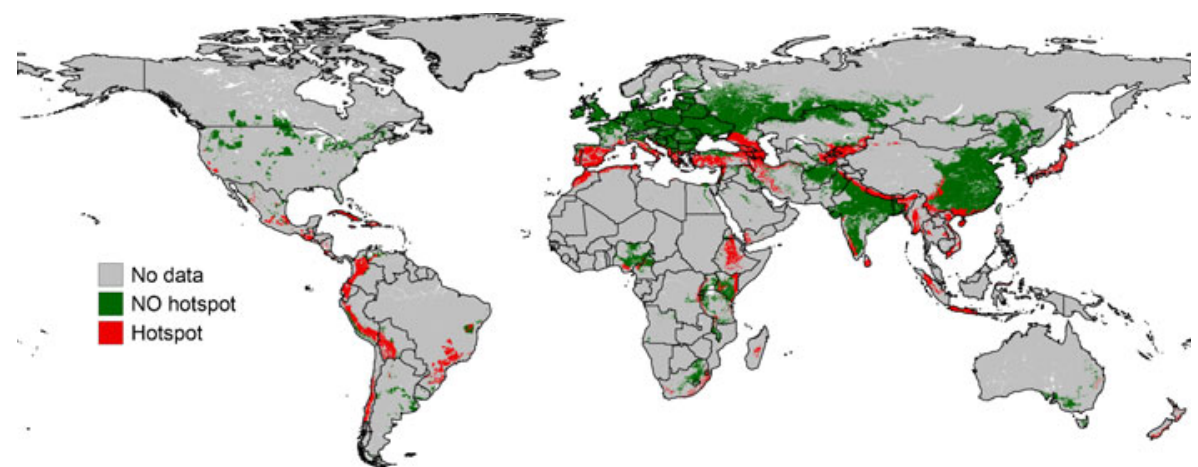

Fig. 6 Grid cells where harvested potato area $>0$ and with (red) or without (green) a biodiversity hotspot according to Conservation International (http://www.conservation.org)

Japan, and Egypt. Finally, the highest yields (20-50 t per hectare) are situated in North America and Northwest Europe. These high yields are made possible by high input levels in rain-fed and irrigated cropping systems combined with long frost-free periods with long days and high solar input. A cropping season in these regions may exceed 150 growing days from planting to harvest.

Where low yields are combined with steep slopes, potato cultivation has a very high environmental impact because large( $\mathrm{r}$ ) areas are under risk of soil loss by erosion. These problems have been documented (e.g., Griffin and Honeycutt 2009; Kagabo et al. 2013; Tiessen et al. 2010). Similarly, it has been documented that irrigated cultivation in the desert such as in the western parts of North America and the Central Andes leads to depletion of water reserves and large losses of N. For each of the areas that our method defines as to be at risk for $\mathrm{N}$ losses, ample documentation can be found: North America (Davenport et al. 2005; Weinert et al. 2002), Northwest Europe (e.g., Boumans and Fraters 2011; Schröder et al. 2007), South Africa (e.g., Franke et al. 2011), and Australia (e.g., Lisson and Cotching 2011).

A limitation of the current data is that use of $\mathrm{N}$ fertilizer is available only on a percountry basis. For large countries, especially if they have two or more distinct potatogrowing areas, this can lead to large errors. For example, in the USA, yields of irrigated potato cultivation in the western deserts are at least $70 \mathrm{t} \mathrm{ha}^{-1}$, while yields in shortseason cultivation in the North Atlantic states are no more than $35 \mathrm{t} \mathrm{ha}^{-1}$ (USDA-ERS 2008). It is unlikely that $\mathrm{N}$ input is the same in these different systems. One possible way to address this problem is to re-allocate $\mathrm{N}$ fertilizer use within a country according to the yield level of each potato-producing grid cell while keeping the total fertilizer $\mathrm{N}$ use of a country at the same level.

Wet and cool regions of the world are most prone to late blight. Dry land potatoes grown under irrigation suffer less from the disease such as the western parts of North America, southern Europe, and much of continental Asia. The important potato production region in central and Eastern Europe have an intermediate position regarding late blight pressure because rainfall is less excessive than in the other continental short summer crops such as in northern China that experience cold dry winters and rainy warm summers.

Little information is available on the carbon footprint of global potato production. A recent source is Haverkort and Hillier (2011), who give 71 to $115 \mathrm{~kg} \mathrm{CO}_{2}$-eq t ${ }^{-1}$ for starch and seed production systems in the Netherlands. The numbers fall mostly in the same 
range as calculated in our study. However, our calculation of the carbon footprint is prone to errors, perhaps more than some other indicators. For one, $\mathrm{N}$ fertilizer use is an important determinant, but this input is only available on a per-country basis. This means that carbon footprint in our method may show within-country artefacts. Another point is that carbon footprint is obtained by dividing by yield, causing relatively small inaccuracies in yield to have a relatively large effect on the carbon footprint. This is illustrated by comparing western India (approximately Gujarat) and north-central India (approximately Maharashtra and Madhya Pradesh): yield (Haverkort et al. (2014), Fig. 1) and carbon footprint (Fig. 5) show much similarity, even though $\mathrm{N}$ surplus is the same (Fig. 3).

The use of a threshold for each indicator makes it possible to quickly focus on grid cells where there is a hotspot, i.e., areas where the values for that indicator are unfavorable. However, there are several caveats that need to be considered when using these thresholds.

It is in principle not possible to define a threshold that indicates a sustainable agricultural production system. The reason is that agriculture is only a part of the economy. Taking the case of climate change, it is estimated that in order to avoid irreversible and catastrophic effects, atmospheric $\mathrm{CO}_{2}$ concentration must be reduced to below $350 \mathrm{ppm}$ (Hansen et al. 2008). In order to reach this goal, global $\mathrm{CO}_{2}$ emission must be reduced relative to the present value. But this statement says nothing about how this reduction can or should be distributed over the sectors of the economy and over countries. This is the reason that in this paper we consider quantiles for the indicator GHG emissions: regardless of the global situation with respect to climate change, those areas where GHG emission per ton is above the 80th percentile surely deserve attention.

While emission of GHG has a global impact, the impact of emission of nitrate is local. In many places legislation is in place which seeks to limit the impact of nitrate emissions, for example by regulating the amount of fertilizers and manures that can be used and the manner of their use, or by imposing a limit on groundwater nitrate concentration. These local definitions of what is considered acceptable environmental impact are the result of a political process and may not indicate sustainability but they do indicate the limits within agriculture has to operate. Thus, in this paper the threshold for $\mathrm{N}$ surplus is based on an environmental impact that is considered acceptable as expressed through legislation.

Biodiversity is important to humans, but there is as yet no way to define even approximately how much biodiversity we need. For biodiversity we consider those grid cells worthy of attention that coincide with a biodiversity hotspot. Other maps can be taken as a basis: for example, potato cultivation that takes place in a national park would also merit close inspection.

The three different ways of deriving threshold values - (1) based on the range of performances observed (yield, carbon footprint, erosion risk, precipitation deficit, and biocide use); (2) acceptable environmental impact as expressed through legislation (N surplus); and (3) environmental impact based on arguments expressed in public debate (biodiversity) - imply that the meaning of exceeding a threshold may be different. Any discussion about indicator values for a particular cell should be held with the above considerations in mind.

Indicators can be expressed in several ways: per hectare, per ton of product, or per cell. In any of these cases, the indicator may be expressed relative to a target or potential value. The potential yield of a crop is ultimately limited by temperature, solar radiation, and the genetic potential of the crop. Rather than expressing yield on a per 
hectare basis, it could be expressed as a percentage of the potential yield (Kropff et al. 2001), which can be calculated for each grid cell based on local weather characteristics. This was beyond the scope of the present study, but can be taken into account in further development of the tool.

The impact of a given value of an indicator may depend on the area in which it takes place, and possibly also on the values of other indicators. For example, in the accompanying paper precipitation deficit is used as a proxy for the need to use water for irrigation. The impact of using water in a region where there is an abundant source of water will be less than the impact of using the same amount of water in a waterscarce region. As another example, a certain value of $\mathrm{N}$ surplus may be acceptable if only a small fraction of the land is used for cultivation, while the same $\mathrm{N}$ surplus may lead to a large $\mathrm{N}$ emission in that area and thus be unacceptable when a large fraction of the land is used for cultivation.

The indicators used in this paper were calculated using coarse input data and with coarse process descriptions. Consequently, an indicator value may not be representative for the whole cell or indeed any part of it. This means one must be careful with interpreting the indicator values given in this paper - they are meant to illustrate a possible approach. Conclusions can only be drawn after our indicator values have been confirmed locally.

In order to work on improving the sustainability of an agricultural production system, one does not need to know what thresholds to aim for. For example, it is certainly not the case that a potato producer with GHG emissions of less than $140 \mathrm{~kg} \mathrm{CO}_{2}$-eq $\mathrm{t}^{-1}$ (the 80th percentile) should feel free to neglect opportunities to reduce his or her carbon footprint.

The tool has been implemented for potato but can be expanded to include other crops in a straightforward way. In order to include a new crop, one would have to describe the hotspots, define methods to calculate them, collect the data, and draw the maps. The procedure for calculating the hotspot $\mathrm{N}$ surplus would be virtually identical for all crops. The procedure for the hotspot precipitation deficit requires a definition of the growing period of the crop. For potato we defined growth period using the approach of Verhagen et al. (2000). For other crops similar procedures would have to be adopted. The hotspot water erosion is of particular importance to potato. However, erosion (water and wind) is clearly also an issue in many other crops. It is likely that new crops will have a large overlap with potato in terms of hotspots, calculations, and data.

Currently, the tool considers single crops. However, a crop is almost always grown in a crop rotation, and sometimes in combination with livestock. Consequently, it is not always clear to which crop in the rotation an impact (e.g., loss of N, or loss of soil, or tillage to achieve a desired condition of the soil) must be ascribed. It could be argued that a full assessment of the environmental impact of growing a particular crop can only be made by considering the entire production system. Considering the production system instead of single crops would increase the data requirements and the complexity of the tool.

The tool described aims to locate likely hotspot areas so that efforts to increase sustainability can be efficiently targeted. Sustainability is likely to remain a concern for the foreseeable future and a new assessment will have to be made whenever input data have changed significantly. The usefulness of the tool is thus in part determined by the frequency with which the system will have to be updated and what effort will be required.

The tool described is low resolution, both in terms of spatial scale (cells of maximum $8,000 \mathrm{ha}$ ) and in terms of process description. This is a better resolution than the hotspot 
approach of TSC, but might still be considered too coarse in areas where differences within a cell are large. The tool can easily be refined in both respects. Where information at sub-cell level is available, the calculations can be done at sub-cell level down to the level of individual fields. Similarly, processes can be described in more detail. For example, a calculation could be added to calculate the fraction of $\mathrm{N}$ surplus that is lost in the form of nitrate leaching.

There is a plethora of methods to assess sustainability, including LCA, indicator-based methods (Bockstaller et al. 1997, 2009), multi-criteria analysis (MCA), and total factor productivity (TFP) (Barnett et al. 1995; Färe et al. 2012; Glendining et al. 2009). Any of these methods can in principle be used to assess the sustainability of production in each grid cell. The most important limitation is that in many cases not all information that is needed will be available. It is out of the question that enough information will be available in our tool to perform even a simple LCA. On the other hand, nitrogen surplus is one of the hotspots in our tool and it is also one of the indicators proposed by Bockstaller et al. (1997). Methods such as MCA and TFP aim to assess sustainability by considering both good outputs (e.g., yield and landscape value) and so-called bad outputs (e.g., loss of $\mathrm{N}$ and emission of GHG). The scores of a particular grid cell could be summarized by any of these methods to provide an overall assessment of the sustainability of the cell. Such an assessment would not have to be limited to one crop, but could instead include all outputs (good and bad) from all crops grown in a grid cell. While it would be an interesting exercise to compute an overall index of sustainability for each grid cell, we feel that the current goal of identifying hotspot areas in potato production is best served by focusing on individual hotspots rather than on some form of aggregation.

\section{Conclusions}

We present a tool to identify sustainability hotspots for potato production that uses readily available data with global coverage and easily understood calculations. The tool produces realistic results which can be used to target improvement efforts and thus make efficient use of limited resources. The tool can be expanded to produce similar results for other crops and can easily be adjusted by using other spatial resolutions and more detailed process descriptions.

Acknowledgments This research was financed by the Netherlands Ministry of Economic Affairs within the framework of the "Kennisbasis I: Global Food Security: Scarcity and Transition" and "Kennisbasis V: Value Chains" strategic research programs. We are grateful to Dr. K. Boone (LEI, The Hague, Netherlands) for discussions about the goal and methods of The Sustainability Consortium. We thank Dr. C.M. Slay (University of Arkansas, Lafayette, AK, USA) for discussions on the Commodity Supply Chain Mapping Project.

\section{References}

ADAS. (2007) Diffuse nitrate pollution from agriculture - strategies for reducing nitrate leaching. ADAS report to Defra - supporting paper D3 for the consultation on implementation of the Nitrates Directive in England. Available online at http://archive.defra.gov.uk/environment/quality/water/waterquality/diffuse/ nitrate/documents/consultation-supportdocs/d3-inventory-measures.pdf 
Barnett V, Payne R, Steiner R (1995) Agricultural sustainability: economic, environmental and statistical considerations. Wiley, Chichester

Bockstaller C, Girardin P, van der Werf HMG (1997) Use of agro-ecological indicators for the evaluation of farming systems. Eur J Agron 7:261-270

Bockstaller C, Guichard L, Keichinger O, Girardin P, Galan MB, Gaillard G (2009) Comparison of methods to assess the sustainability of agricultural systems. A review. Agron Sustain Dev 29:223-235

Boumans LJM, Fraters B (2011) Nitraatconcentraties in het bovenste grondwater van de zandregio en de invloed van het mestbeleid. Visualisatie afname in de periode 1992 tot $2009=$ Nitrate concentrations in the upper groundwater of the sand region and the effects of manure policy. Visualisation of the decrease from 1992 to 2009. RIVM Rapport 680717020/2011. Available online at http://www.rivm.nl/Bibliotheek/ Wetenschappelijk/Rapporten/2011/mei/Nitraatconcentraties_in_het_bovenste_grondwater_van_de_ zandregio_en_de_invloed_van_het_Mestbeleid_Visualisatie_afname_in_de_periode_1992_tot_2009 . RIVM, Bithoven, The Netherlands

Conservation International (2011) Hotspots Revisted dataset. Available online http://www.conservation.org/ where/priority_areas/hotspots/Pages/hotspots_main.aspx

Davenport JR, Milburn PH, Rosen CJ, Thornton RE (2005) Environmental impacts of potato nutrient management. Am J Potato Res 82:321-328

Färe R, Grosskopf S, Lundgren T, Marklund P-O, Zhou W (2012) Productivity: should we include bads?, CERE-the Center for Environmental and Resource Economics

Fertistat (2012) Fertilizer use statistics. Available online at http://www.fao.org/ag/agp/fertistat/. Food and Agriculture Organisation of the United Nations, Plant Production and Protection Division. http://www. Fao.Org/Ag/Agp/Fertistat/ (accessed 29-Oct-2012)

Fischer G, Nachtergaele F, Prieler S, van Velthuizen HT, Verelst L, Wiberg D (2008) Global Agro-ecological Zones Assessment for Agriculture (GAEZ 2008). IIASA, Laxenburg, Austria and FAO, Rome, Italy

Franke AC, Steyn JM, Ranger KS, Haverkort AJ (2011) Developing environmental principles, criteria, indicators and norms for potato production in South Africa through field surveys and modelling. Agric Syst 104:297-306. doi:10.1016/j.agsy.2010.12.001

Giletto CM, Echeverria HE (2013) Nitrogen balance for potato crops in the southeast pampas region, Argentina. Nutrient Cycling In Agroecosystems 95:73-86. doi:10.1007/s10705-012-9549-2

Glendining MJ, Dailey AG, Williams AG, Van Evert FK, Goulding KWT, Whitmore AP (2009) Is it possible to increase the sustainability of arable and ruminant agriculture by reducing inputs? Agric Syst 99:117125

Griffin TS, Honeycutt CW (2009) Effectiveness and efficacy of conservation options after potato harvest. J Environ Qual 38:1627-1635. doi:10.2134/jeq2008.0272

Hansen J, Sato M, Kharecha P, Beerling D, Berner R, Masson-Delmotte V, Pagani M, Raymo M, Royer DL, Zachos JC (2008) Target atmospheric $\mathrm{CO}_{2}$ : where should humanity aim? arXiv preprint arXiv:0804.1126

Haverkort AJ, Hillier JG (2011) Cool farm tool-potato: model description and performance of four production systems. Potato Res 54:355-369. doi:10.1007/s11540-011-9194-1

Haverkort A, De Ruijter FJ, Conijn JG, Van Evert FK, Rutgers B (2014) Worldwide sustainability hot spots in potato cultivation. 1. Identification and mapping. Potato Research. doi:10.1007/s11540-013-9247-8

IPCC (2006) IPCC Guidelines for national greenhouse gas inventories, Volume 4, Agriculture, forestry and other land use. Chapter 11: $\mathrm{N}_{2} \mathrm{O}$ emissions from managed soils, and $\mathrm{CO}_{2}$ emissions from lime and urea application. Accessible at: http://www.ipcc-nggip.iges.or.jp/public/2006gl/vol4.html

Jenssen TK, Kongshaug G (2003) Energy consumption and greenhouse gas emissions in fertiliser production. Proceedings no: 509. The International Fertiliser Society, York, UK

Kagabo DM, Stroosnijder L, Visser SM, Moore D (2013) Soil erosion, soil fertility and crop yield on slowforming terraces in the highlands of Buberuka, Rwanda. Soil \& Tillage Research 128:23-29. doi:10.1016/ j.still.2012.11.002

Kropff MJ, Bouma J, Jones JW (2001) Systems approaches for the design of sustainable agro-ecosystems. Agric Syst 70:369-393

Lisson SN, Cotching WE (2011) Modelling the fate of water and nitrogen in the mixed vegetable farming systems of northern Tasmania, Australia. Agric Syst 104:600-608. doi:10.1016/j.agsy.2011.06.002

Monfreda C, Ramankutty N, Foley JA (2008) Farming the planet: 2. Geographic distribution of crop areas, yields, physiological types, and net primary production in the year 2000, Global Biogeochem. Cycles, 22, GB1022. doi:10.1029/2007GB002947

Myers N (1988) Threatened biotas: "Hot spots" in tropical forests 8:187-208. DOI: 10.1007/bf02240252

Myers N (1990) The biodiversity challenge. Expanded Hot-Spots Anal 10:243-256. doi:10.1007/bf02239720

Pimentel D, Wilson C, McCullum C, Huang R, Dwen P, Flack J, Tran Q, Saltman T, Cliff B (1997) Economic and environmental benefits of biodiversity. Bioscience 47:747-757. doi:10.2307/1313097 
PPO (2012) Kwantitatieve Informatie Akkerbouw en Vollegrondsgroenteteelt 2012 Praktijkonderzoek Plant \& Omgeving (PPO), Lelystad

Pretty J, Smith G, Goulding KWT, Groves SJ, Henderson I, Hine RE, King V, van Oostrum J, Pendlington DJ, Vis JK, Walter C (2008a) Multi-year assessment of Unilever's progress towards agricultural sustainability II: outcomes for peas (UK), spinach (Germany, Italy), tomatoes (Australia, Brazil, Greece, USA), tea (Kenya, Tanzania, India) and oil palm (Ghana). Int J Agric Sustain 6:63-88. doi:10.3763/ijas.2007.0323

Pretty J, Smith G, Goulding KWT, Groves SJ, Henderson I, Hine RE, King V, van Oostrum J, Pendlington DJ, Vis JK, Walter C (2008b) Multi-year assessment of Unilever's progress towards agricultural sustainability I: indicators, methodology and pilot farm results. Int J Agric Sustain 6:37-62. doi:10.3763/ijas.2007.0322

Schröder JJ, Aarts HFM, van Middelkoop JC, Schils RLM, Velthof GL, Fraters B, Willems WJ (2007) Permissible manure and fertilizer use in dairy farming systems on sandy soils in The Netherlands to comply with the Nitrates Directive target. Eur J Agron 27:102-114. doi:10.1016/j.eja.2007.02.008

Siebert S, Döll P, Hoogeveen J, Faures JM, Frenken K, Feick S (2005) Development and validation of the global map of irrigation areas. Hydrol Earth Syst Sci Disc 2:1299-1327

Siebert S, Döll P, Feick S, Hoogeveen J, Frenken K (2007) Global Map of Irrigation Areas version 4.0.1. Johann Wolfgang Goethe University, Frankfurt am Main, Germany/Food and Agriculture Organization of the United Nations, Rome, Italy (http:/www.fao.org/nr/water/aquastat/irrigationmap/index10.stm)

Smith SV, Bullock SH, Hinojosa-Corona A, Franco-Vizcaino E, Escoto-Rodriguez M, Kretzschmar TG, Farfan LM, Salazar-Cesena JM (2007) Soil erosion and significance for carbon fluxes in a mountainous Mediterranean-climate watershed. Ecol Appl 17:1379-1387. doi:10.1890/06-0615.1

Sparks AH (2009) Disease risk mapping with metamodels for coarse resolution predictors - global potato late blight risk now and under future climate conditions. Dissertation Kansas State University, Manhattan, Kansas (http://krex.k-state.edu/dspace/bitstream/handle/2097/2341/AdamSparks2009.pdf?sequence=5)

Sparks A, Forbes G, Hijmans R, Garrett K (2011) A metamodeling framework for extending the application domain of process-based ecological models. Ecosphere 2. doi:10.1890/ES11-00128.1

Tiessen KHD, Sancho FM, Lobb DA, Mehuys GR (2010) Assessment of tillage translocation and erosion by the disk plow on steepland Andisols in Costa Rica. J Soil Water Conserv 65:316-328. doi:10.2489/jswc. 65.5.316

Turpie JK, Heydenrych BJ, Lamberth SJ (2003) Economic value of terrestrial and marine biodiversity in the Cape Floristic Region: implications for defining effective and socially optimal conservation strategies. Biol Conserv 112:233-251. doi:10.1016/s0006-3207(02)00398-1

USDA-ERS (2008) U.S. Potato Statistics, 1960-2006. Economic Research Service, United States Department of Agriculture. Available online at http://usda.mannlib.cornell.edu/MannUsda/viewDocumentInfo.do? documentID=1235. Retrieved 10 October 2013

Verhagen A, Grashoff C. Uithol PWJ, Haverkort AJ (2000) Agro-ecological zoning of potato. Wageningen, Plant Research International, Report 7, Wageningen

Weinert TL, Pan WL, Moneymaker MR, Santo GS, Stevens RG (2002) Nitrogen recycling by nonleguminous winter cover crops to reduce leaching in potato rotations. Agron J 94:365-372 